\title{
Prostate Hemangioma
}

National Cancer Institute

\section{Source}

National Cancer Institute. Prostate Hemangioma. NCI Thesaurus. Code C161581.

A rare hemangioma that arises from the prostate gland. 